\title{
Breach of Notarial Deed for Peace under Indonesian Civil Law Perspective
}

\author{
Hazar Kusmayanti, Yola Maulin, Eidy Sandra \\ Faculty of Law, Universitas Padjadjaran Bandung, Indonesia. E-mail: hazar.kusmayanti@unpad.ac.id \\ Faculty of Law, Universitas Padjadjaran Bandung, Indonesia. E-mail: yola.maulin@gmail.com \\ Faculty of Law, Universitas Padjadjaran Bandung, Indonesia. E-mail: eidysandra@gmail.com
}

\begin{tabular}{l} 
ARTICLE INFO \\
\hline Keywords: \\
Peace Agreement, Ne bis \\
in Idem Principle, \\
Lawsuit, Breach of \\
Contract, Civil Law. \\
\\
How to cite: \\
Kusmayanti, H., Maulin, \\
Y., Sandra, E. Breach of \\
Contract on Notarial Deed \\
Peace in Indonesia Civil \\
Law Perspective. MEDIA \\
HUKUM, 62 274 \\
387656 (Ext. 220$)$ \\
\\
Article History \\
Received: 04/05/2019 \\
Reviewed: 19/06/2019 \\
Revised: \\
Accepted: 26/06/2019 \\
\hline
\end{tabular}

\begin{abstract}
This paper discusses the application of the principle of 'ne bis in idem' in lawsuit relating to the breach of the notarial deed for peace and the legal force of notarial deed for peace based on the Civil Code and the Civil Procedure (HIR). This research use primary and secondary legal materials were collected through both library research and field work. It is found that with regards to Article 1917 of the Civil Code and Article 130 Paragraph (2) the Civil Procedure (HIR), the principle of 'ne bis in idem' is not contained in a lawsuit against the breach of notarial deed for peace. The principle of ne bis in idem which is implicitly is not contained in a breach of contract lawsuit filed against a party that does not implement a notarial deed of peace. This is due to the notarial deed of peace in the case was not confirmed by the court judge, so that the deed of peace was not equalized as a court ruling that had permanent legal force (inkracht van gewijsde), but was merely an ordinary agreement binding on the parties. The legal force of the notarial deed for peace is the same as the authentic deed as outlined in Article 1870 of the Civil Code and Article 165 of the Civil Procedure (HIR).
\end{abstract}

DOI: 10.18196/jmh.20190121

Copyright @ 2019 MEDIA HUKUM. All rights reserved.

\section{Introduction}

Humans, as beings or individuals tend to gather with other individuals and thus form groups of people who live together. The tendency of living together as a group leads human to be called as social beings. ${ }^{1}$ Considering that humans are born as social beings, to fulfill their diverse needs, they need a helping hand from other humans. One way of the fulfillment of their life necessities that can be done by humans is to interact

\footnotetext{
${ }^{1}$ Kusumaatmadja, M. (et.al.). (2000). Pengantar Ilmu Hukum Suatu Pengenalan Pertama Ruang Lingkup Berlakunya Ilmu Hukum, Bandung: Alumni, p. 12.
} 
with other humans, by conducting an agreement, among other things. Based on Article 1313 of the Civil Code (from now on referred to as the Civil Code) an agreement is an act in which one person or more ties himself to one or more other people, so that it can be known that at least two or more people are required to agree.

The meaning of the agreement, as stated in Article 1313 of the Civil Code contains the principle of the binding power of the agreement or commonly referred to as the principle of pacta sunt servanda. The principle means that each agreement that is legally made and by applicable law, and also by customs and propriety in the community, then the clauses contained in the agreement bind the parties that make it where the binding power is equivalent to the binding power of a law. ${ }^{2}$ The consequence of the existence of the principle of pacta sunt servanda is that the parties who agree must fulfill their contractual obligation.

Whereas it is a known fact that the agreement is one of the sources of engagement. An engagement that arises due to the agreement causing legal consequences for both parties that is for the debtor in the form of an obligation to fulfill the performance and for the creditor in the form of the right to obtain performances. The performance itself is an object of engagement in which consists of three types, which are giving something, to do or not to do something.

In practice, there is a possibility for one of the parties not to be able to properly fulfill the agreement which has determined all the rights and obligations. Such a situation is commonly referred to as a breach of contract, which is a condition where one party cannot fulfill the performance as agreed in the agreement that is not due to force majeur (overmacht).

Legal consequences arising from the breach of contract include providing the rights for parties who feel disadvantaged to demand compensation from those who breached the contract. The problem will be resolved when the party who breached the contract is willing to fulfill the compensation claim, but it is not uncommon to find that the party who breached the contract is not willing to fulfill the compensation claim and this can lead to a dispute between the parties.

Disputes between parties that occur due to the breach of contract gives the aggrieved party the right to file a claim to the District Court, whether the District Court in accordance with the legal domicile agreed upon by the parties in the agreement or the District Court within the jurisdiction where the defendant resides (principle of actor sequitur forum rei), except when the defendant does not have a known place of residence or a real place of residence or if the defendant is not known then the claim is submitted to the District Court in the plaintiff's residence. ${ }^{3}$

Based on Article 130 Paragraph (1) Herzien Inlandsch Reglement (herein after referred to as HIR), the judge should encourage litigants to pursue peace effort beforehand. The peace effort can even be implemented throughout the case investigation process. The peace effort, which is the way to resolve disputes through the negotiation process to obtain agreement between the parties with the help of mediators, is carried out in court through a mediation process. The mediator in the mediation process acts as a neutral

\footnotetext{
${ }^{2}$ Fuady, M. (2013). Teori-Teori Besar dalam Hukum (Grand Theory). Jakarta: Kencana p. 210.

${ }^{3}$ Mertokusumo, S. (2009). Hukum Acara Perdata Indonesia, Yogyakarta: Liberty, p. 89.
} 
party that helps the parties to look for various possibilities for resolving disputes without using a way to execute or enforce a settlement.

Mediation is not only a part of the litigation settlement process in civil disputes but also a way of resolving non-litigation disputes. The peace agreement which is obtained through the process of litigation and non-litigation mediation must be made in written form, for the reason that the peace agreement is one form of a formal agreement. A peace agreement will become illegal and not binding on the parties if it is not made in written form.

Peace agreement as the result of the non-litigation mediation process can be made in the form of an authentic deed or an under-hand deed. The authentic deed is a deed which form is determined by the law and made by or in the presence of a ruling general official for that in the place where the deed was made, while the under hand deed is a deed which deliberately made by the parties to prove without assistance from a public official. ${ }^{4}$

As it is known that one of the public officials authorized to make authentic deed is a notary. A notary has the authority to make authentic deeds regarding all acts, agreements, and stipulations required by legislation and those desired by interested parties to be stated in the authentic deed.

Based on Article 36 Paragraph (1) Republic of Indonesia Supreme Court Regulation Number 01 of 2016 on Procedure of Mediation in Courts (Supreme Court Decree on the Procedure of Mediation in Courts) states that peace agreements which are obtained through a process of non-litigation mediation can be strengthened in the form of a deed of peace by filing a lawsuit against authorized court. The peace agreement in terms of being strengthened into a deed of peace will be equalized as a court decision that has permanent legal force (inkracht van gewijsde), whereas if it is not enforced into a deed of peace, the agreement will only be a normal agreement subject to the provisions in Article 1338 of the Indonesian Civil Code.

Although the disputes that occur between parties have been resolved by the existence of a deed of peace or peace does not rule out the possibility for one party denying the contents of the deed and the peace agreement or it can be said that there has been a breach of contract. That is what occurred in the case with case No. 577/Pdt.G/ 2012/PN. Bdg and No. 29/Pdt.G/2008/PN. Tmk where one party has breached the contract on the contents of the deed of peace made before the notary (notarial deed of peace).

The two cases above have obviously deviated from the concept of peace itself as stated in Article 1851 of the Civil Code which states that peace is an agreement in which both parties submit, promise or hold an item, end a case that is dependent or prevent the arising of a case.

This paper discusses the application of the principle of 'ne bis in idem' in lawsuit relating to the breach of the notarial deed for peace and the legal force of notarial deed for peace based on the Civil Code and the Civil Procedure (HIR). This paper contribute to the Civil Law science, competence of author and educate for society.

\footnotetext{
${ }^{4}$ Ibid. p.155-160.
} 


\section{Method}

The type of this research is normative juridical research that prioritizes the study of secondary data which consists of primary, secondary, and tertiary legal materials. Data collection is done through library research and field work. Field work is done through interview with notary located in Bandung to obtain in-depth and complete data related to the problems to be studied.

\section{Analysis and Results}

\subsection{Application of the Principle of Ne Bis In Idem}

Unlike criminal law which has regulated the principle of ne bis in idem explicitly in Article 76 of the Criminal Code (KUHP), up to now, civil law has no legislation yet that explicitly regulate the principle of ne bis in idem. This does not mean that the principle of ne bis in idem is not known in civil law.

Related to that, M. Yahya Harahap, who is one of the law experts on the Civil Law, stated that the principle of ne bis in idem is implicitly regulated in Article 1917 of the Civil Code. The contents of Article 1917 of the Civil Code.

Based on the contents of Article 1917 of the Civil Code above, M. Yahya Harahap then concludes that for a claim to be declared to contain the principle of ne bis in idem, the claim must cumulatively fulfil the following conditions:

a. The last filed suit has previously been sued.

b. For the previous case, there has been a judge's decision that has permanent legal force, and the decision is positive. The judge's decision is said to have permanent legal force when the right to file ordinary remedies to that decision has been closed. Moreover, the decision must also be positive in order to be declared to contain the principle of ne bis in idem. Judges' decisions are said to be positive if the judgment and dictum of the decision have determined and completed the status and legal relationship between the parties who litigated the disputed object. A positive judge's decision can be made in the form of a court's decision stating that the plaintiff's claim has been completely rejected or granted in whole or in part. There are exceptions to this provision, in the case of a negative judge's decision or the one which the decision states that an unacceptable claim has contained the principle of ne bis in idem if the claim filed has no legal basis and the principle of ne bis in idem is attached to the claim submitted.

c. Subjects or parties who are in the same case. That is, the subject who is the party to the previous case with the case submitted later to the court is the same.

d. The same object of the claim. That is, the object of the claim in the previous case with the case that was last submitted to the court is the same.

The conditions stated above then in judicial practice are often used as guidelines by the judge to determine whether a case that was submitted to him to be examined and tried has contained the principle of ne bis in idem or not.

\footnotetext{
${ }^{5}$ Harahap, M.Y. (2008). Hukum Acara Perdata, Jakarta: Sinar Grafika, p. 441-448.
} 
The following of the opinion of M. Yahya Harahap regarding the principle of ne bis in idem by the judges of the court was in accordance with the provisions of Article 10 Paragraph (1) of Law Number 48 of 2009 concerning Supreme Court (Law of Supreme Court) which prohibits judges from refusing to examine, adjudicate, and decide on a case that is submitted under the pretext that the law does not exist or is unclear.

The judge must act on his initiative to try and decide the case if the legislation related to the case is absent or unclear. In this matter, the judge must make legal discoveries, and one of the sources for the judge in finding the law comes from the opinion of a prominent legal scholar or doctrine. ${ }^{6}$

The presence or absence of the principle of ne bis in idem in a lawsuit of breach of contract that is filed against a party who does not implement the notarial deed of peace reviewed from Article 1917 of the Civil Code, the author will analyse the four conditions so that a claim can be stated that it has contained the principle of ne bis in idem as stated above is associated with two examples of cases found.

a. The Last Filed Suit Has Previously Been Sued

The requirement of the first point is not fulfilled by two examples of cases of breach of contract that the author found, due to the differences between the final claim filed with the previous lawsuit in two cases.

In the first case that occurred in Bandung, the claim with case number 120/ Pdt.G/1999/PN.Bdg was filed by the Plaintiff for the reason that the Defendants had breached the contract on the contents of the debt agreement that had been made, while the claim with case number 577/Pdt.G /2012/PN. Bdg was filed by the Plaintiff by for the reason that the Defendants had breached the contract on the contents of the notarial deed of peace that had been made.

In the second case that occurred in Mimika, the claim with case number 19/ Pdt.G/2002/PA.Mmk was filed by the Defendant by the reason of he felt that he had the right to obtain the joint assets he obtained during the marriage with the Plaintiff, while the claim with case number 29/Pdt.G/2008/PN.Tmk was submitted by the Plaintiff by reason of the Defendant had breached the contract on the contents of the notarial deed of peace.

b. Previous Cases has Permanent Legal Force (Inkracht Van Gewijsde) and is Positive

It should be noted that the second point requirement is closely related to the first point requirement stated above, that is the existence of two cases with the same claim argument where the previous case has been ruled by a court decision that has permanent legal force and is positive. Based on that, it can be concluded that the second point requirement is also not fulfilled in the two case examples that the author found.

c. The Subject who Becomes a Party to the Case is the Same

The third point requirement has been fulfilled by both of the cases of breach of contract claims that the author found, where in the first case that occurred in Bandung it can be seen that the subject in case number 120/Pdt.G/1999/PN. Bdg is Afih Tanuwidjaja (Plaintiff) against Adang Rikman (Defendant I) and PT. Sabuma

\footnotetext{
${ }^{6}$ Ardhiwisastra, Y.B. (2000). Penafsiran dan Konstruksi Hukum, Bandung: PT. Alumni, p.43.
} 
Inti Persada (Defendant II), while in case number 577/Pdt.G/2012 / PN. Bdg there is another subject included, that is the Head of Land Agency of Sumedang Regency as Co-Defendant.

The plaintiff in the case number 577/Pdt.G/2012/PN. Bdg although has included the Head of Land Agency of Sumedang Regency as Co-Defendant, but basically the subject in case number 120/Pdt.G/1999/PN. Bdg and number 577/Pdt.G/2012/PN. $\mathrm{Bdg}$ is the same, because Co-Defendants are people who do not control the disputed item or are not obliged to do something, but for the sake of the completeness a person's claim, that person must be included only to submit and obey to the decision of the court.7

Proceeding to the second case example that occurred in Mimika where the subject who was the party to the case number 19/Pdt.G/2002/PA. Mmk is H. M. Yusuf Rahman (Plaintiff) against Hj. Rusnah Patompo (Defendant), while the subject in case number 29/Pdt.G/2008/PN. Tmk is Hj. Rusnah Patompo (Plaintiff) against H. M. Yusuf Rahman (Defendant). Although the position of the subject in both cases is different, in principle, the subject in both cases is the same.

d. The Objects in the Last Submitted Suit with Objects in the Previous Case are the Same

Based on the decision of the Bandung District Court Number 120/Pdt.G/1999/PN. $\mathrm{Bdg}$, it can be seen that the object in the case is the repayment of all debts that must be paid by the Defendants to the Plaintiff based on the debt agreement made in 1998, while the object in the case number 577/Pdt.G/2012/PN. Bdg is the fulfillment of the contents of the notarial deed of peace in the form of submitting a number of effective plots belonging to the Defendants to the Plaintiff.

Based on the explanation above, it can be concluded that the object in case number 120/Pdt.G/1999/PN. Bdg and number 577/Pdt.G/2012/PN. Bdg is different, so the case does not meet the fourth point requirement in order that the claim can be declared to contain the principle of ne bis in idem.

Proceeding to the second case that occurred in Mimika, where it can be seen that the object in case number 19/Pdt.G/2002/PA. Mmk is the distribution of shared assets entitled to H. M. Yusuf Rahman, while the object in case number 29/Pdt.G/2008/PN. Tmk is the fulfillment of the contents of the notarial deed of peace, in which the contents are essentially about joint assets.

Based on what mentioned above, it can be concluded that the disputed object in case number 19/Pdt.G/2002/PA. Mmk and number 29/Pdt.G/2008/PN. Tmk is the same, so that the case has fulfilled the fourth point requirement in order that a claim can be stated to contain the principle of ne bis in idem.

Based on the matters described above if it can be concluded that the breach of contract lawsuit filed against the party who did not implement the notarial deed of peace is not contained the principle of ne bis in idem. This is due to the two case examples described above have not cumulatively fulfilled the conditions so that a claim can be declared to contain the principle of ne bis in idem.

\footnotetext{
${ }^{7}$ Sutantio, R. (et.al.). (2005). Hukum Acara Perdata dalam Teori dan Praktek, Mandar Maju, Bandung, p.2.
} 
Aside from viewing the application of the principle of ne bis in idem in cases of defaults against parties who do not implement the notarial deed of peace based on the Civil Code, the author will also review them based on the provisions in the HIR.

Just as the Civil Code that does not explicitly regulate the principle of ne bis in idem, HIR also does not regulate it explicitly. In connection to that, since what will be discussed in this case is the application of the principle of ne bis in idem in breach of contract claim on the contents of a notarial deed of peace, the approach can be made according to the provisions contained in Article 130 Paragraph (2) HIR.

Article 130 Paragraph (2) HIR is a provision regulating the legal power of the deed of peace as a peace agreement that is obtained through a litigation mediation process in which the deed has been confirmed by the judge examining the case concerned, so that the deed has the same legal force as the court decision that has permanent legal force (inkracht van gewijsde).

Related to the above, on account of the fact that the notarial deed of peace in the two cases that the author has described is not affirmed whether or not it has been confirmed by a judge and since there has been a breach of contract claim against the party who did not implement the notarial deed of peace, it can be concluded that the deed was not confirmed by a judge. Thus, the notarial deed of peace has only a legal power as an ordinary agreement, so that in the event of a breach of contract, then the aggrieved party cannot immediately request the execution of the deed of peace but must submit a claim first to the competent court.

Based on the above explanation, it can be concluded that the principle of ne bis in idem does not contain in a breach of contract lawsuit filed against the party who did not carry out the notarial deed of peace when reviewed from the provisions of Article 130 Paragraph (2) of the HIR.

\subsection{The Legal Strength of the Notarial Deed of Peace When Sued to the Court Viewed from the Civil Code and the HIR}

The main task of the notary is in accordance with the provisions stated in Article 1 Paragraph (1) of Law Number 02 of 2014 concerning Amendment to Law Number 30 of 2004 concerning the Profession of Notary (Notary Profession Act) is to make authentic deed, but in carrying out his position a notary also has social functions as stipulated in Article 15 Paragraph (2) Letter e of the Notary Profession Act, that is providing legal advice or counseling to the clients related to the making of the deeds.

Article 16 Paragraph (1) Letter e of the Notary Profession Act also imposes an obligation on the notary so that during the term of running the profession, he/she also obliged to provide services to the public who need services in accordance with the provisions of the act, unless there is a reason to refuse. This is in line with the provisions stated in Article 3 Paragraph (6) of the Notary Code of Ethics which states that the notary in implementing his/her position is obliged to prioritize service to the interests of the community and the state.

Based on the explanation above, it can be concluded that although theoretically, the main task of the notary is to make authentic deeds, considering that the needs of the community in the field of law are currently growing, it is possible that a notary can be chosen as a mediator in non-litigation mediation processes. 
The deed of peace as a peace agreement obtained through a process of non-litigation mediation that can be made by the parties before a notary or from now on referred to as a notarial deed of peace. The procedure in making a notarial deed of peace can be divided into four types as follows:

a. The parties in dispute and have yet submitted the dispute to the court, intend to resolve the dispute that occurred through mediation where they agreed to choose a notary as a mediator who tried to help the parties in achieving dispute settlement agreement. The peace agreement resulted from the mediation process was then made in the form of a notarial deed of peace.

b. The parties in dispute and have not submitted the dispute to the court, then among themselves without any intervention from the notary, has been reached a peace agreement. The parties then came before the notary and requested that the agreement they had reached to be made in the form of a notarial deed of peace. The drafting of the notarial deed of peace was intended to guarantee legal certainty of the peace agreement reached by the parties.

c. The parties who are litigating in court, then take a non-litigation mediation process where the notary acts as a mediator. The peace agreement from the mediation process was then desired by the parties to be made in the form of the notarial deed of peace. In this case, the plaintiff will usually immediately withdraw his claim in court because peace has been reached with the defendant.

d. The parties who were litigating in court then reached a peace agreement outside the court among themselves without any intervention from the notary. The parties then came before the notary and requested that the agreement they had reached to be made in the form of a notarial deed of peace. The plaintiff, in this case, will usually immediately withdraw his claim in court because peace has been reached with the defendant.

It has to be noted that in making a notarial deed of peace, in order to be legally valid and binding for the parties, the deed must fulfill the formal and material requirements of authentic deeds, as well as the legal terms of the agreement as stipulated in Article 1320 of the Civil Code. The formal and material requirements of authentic deeds are as follows:

a. Formal Terms

1) Made before an authorized official;

2) Attended by parties;

3) Parties are known or introduced to officials;

4) Attended by two witnesses;

5) Mention the identity of officials, parties, and witnesses;

6) Mention the location and date of making the deed;

7) The official must read the deed before the parties;

8) Signed by officials, parties, and witnesses.

b. Material Requirements

1) Contains information about the agreement of the parties;

2) Such information concerning legal actions or legal relations that occur between the parties;

3) The making of a deed is intentionally intended as evidence of an act or legal relationship between the parties.

\footnotetext{
${ }^{8}$ Harahap, M.Y. Op.Cit, p. 574-580.
} 
The notarial deed of peace that has been made by the parties in practice does not rule out the possibility that one party cannot implement the obligations as specified in the deed and it happens not due to an overmacht. This situation which is commonly referred to as a breach of contract and this is what happens in cases number 577/Pdt.G/2012/PN. Bdg and number 29/Pdt.G/2008/PN. Tmk, where one party denies the contents of the notarial deed of peace that has been made.

The breach of contract on the contents of the notarial deed of peace that are the subject of the case in the two cases above then raise the issue of how the legal power possessed by the deed, considering that the deed of peace that that been confirmed and the one that has yet been confirmed by the judges have different legal powers.

Since the notarial deed of peace in case number 577/Pdt.G/2012/PN. Bdg and number 29/Pdt.G/2008/PN. Tmk is not confirmed by a judge, the deed of peace is only an ordinary agreement that binds the parties. Thus, the breach of contract on the contents of the notarial deed of peace will result in the same legal consequences in the event of a breach of contract on the contents of the agreement as stipulated in Article 1243 of the Civil Code.

Considering that the peace agreement resulting from the non-litigation mediation process can be made in the form of both authentic deeds and underhanded deeds, the legal force of the peace agreement depends on whether the agreement is made in the form of an authentic deed or underhand deed.

A peace agreement will have the same legal power as-as an authentic deed if made by or in the presence of an authorized official, but if a peace agreement is made by or in the presence of an unauthorized official or only made by the parties without assistance from authorized officials, then a peace agreement will only have the same legal power as underhand deed.

Based on the above, it can be concluded that the notarial deed of peace in case Number 577/Pdt.G/2012/PN Bdg and Number 29/Pdt.G/2008/PN. Tmk has the same legal force as the authentic deed for the reason that the deed of peace was made by the parties before a notary where the notary is one of the authorized officials to make authentic deeds.

Related to the matter stated above, it can be seen that if the notarial deed of peace is used as an object in a case in court, then the deed will only be positioned as written evidence as stipulated in Article 1867 of the Civil Code which states that written proof can be done with authentic deeds as well as underhand deeds.

The legal force possessed by the authentic deed which is also owned by the notarial deed of peace has been stipulated in Article 1870 of the Civil Code and Article 165 HIR, which is a perfect and binding evidence for the parties, the heirs of the parties, and those who obtain rights of the parties. ${ }^{9}$ The power of perfect evidence (volledig) and binding (bindende) possessed by authentic deeds is a combination of three types of evidentiary forces attached to it. One type of proof power if not fulfilled, it will eliminate the perfect and binding nature of the authentic deed. The three types of evidentiary power in question are as follows:

a. The Power of Physical Evidence (Uitendige Bewijskracht)

Authentic deeds have the power of physical evidence by the principle of Acta publica probant seseipsa, meaning that a deed which physically appears like an authentic deed and fulfills the requirements prescribed by law, then the deed must be

\footnotetext{
${ }^{9}$ Mertokusumo, S. Op.Cit, p. 157.
} 
considered as an authentic deed insofar as it is not proven otherwise. The burden of proof about whether or not authentic deed is given to people who deny it. ${ }^{10}$

Based on the above, the judge and the parties who litigate in the court must assume that an authentic deed is an authentic deed until the opposing party can prove that the deed is not an authentic deed, for example the deed is legal defect because it has been made by an unauthorized official or an official signature contained in the deed is false. ${ }^{11}$

b. The Power of Formal Evidence (Formele Bewijskracht)

The strength of formal evidence is all information contained in the authentic deed is considered as true has been conveyed by the parties to the official who made it. The presumption of truth also includes the truth of the date of making the deed.12

c. The Power of Material Evidence (Materiele Bewijskracht)

The power of material evidence is related to the truth about what the parties have stated or explained in authentic deeds, so the power of this evidence provides certainty that what is explained by the parties in the deed is really happened.13

As mentioned above, the authentic deed has perfect and binding power of evidence as long as it is not proven to be the opposite, or the evidence of the opponent is not submitted. Authentic deeds are still possible to be submitted the evidence of the opponent because the power of evidence degree does not reach a quality that is decisive or compelling. Evidence that has the power of determining or compelling evidence are, among others, evidence of oaths or claims according to the law.

Opposing evidence that can be submitted to stifle the power of authentic deed is not only limited to evidence in the form of authentic deeds, but also evidence other than authentic deeds can be used as evidence of the opponent to stifle the evidentiary power possessed by authentic deeds.

It should be known that the authentication of authentic deed will be reduced to preliminary written proof if the evidence of the opponent submitted against him is able to stifle the evidentiary power possessed by the authentic deed, so that in this case the authentic deed cannot stand alone to meet the minimum proof limit, at least with one of the other evidence. ${ }^{14}$

Based on the matters described above, since the legal power possessed by the notarial deed of peace in cases number 577/Pdt.G/2012/PN. Bdg and number 29/Pdt.G/2008/PN. Tmk is the same as that is owned by authentic deed, the legal action was taken by the plaintiff is correct in the two cases, that is by filing claim to the competent court in the event of breach of contract on the contents of the notarial deed of peace.

The case will be different if the notarial deed of peace in the two cases above has been confirmed by a court judge. Inauguration of the notarial deed of peace can be implemented by the concerned parties by submitting a lawsuit to the competent court. The inauguration of the deed of peace as referred to above is in accordance with the provisions contained in Article 36 Paragraph (1) of the Procedure of Mediation in Court stating that the peace agreement from the out court dispute resolution process

\footnotetext{
${ }^{10}$ Situmorang, VM. (et.al.), (1993). Grosse Akta dalam Pembuktian dan Eksekusi, Jakarta: PT. Rineka Cipta, p. 109.

${ }^{11}$ Harahap, M.Y. Op. Cit, p.566.

12 Ibid. p.567.

${ }^{13}$ Sutantio, R. Op.Cit, p. 68.

${ }^{14}$ Harahap, M.Y. Op. Cit, p.582
} 
reached by the parties with or without the help of a certified mediator can be confirmed as a deed peace by submitting a lawsuit to the competent court.

It should be known that the deed of peace as referred to in the above Regulation is a deed that contains the contents of the peace document and a judge's decision that strengthens the peace agreement which in practice is often referred to as a peace decision.

Based on the contents of Article 36 Paragraph (1) of the Procedure of Mediation in the Court, it can be concluded that in the event that a peace agreement is requested to be confirmed as deed of peace, the court will decide which decision caused the deed of peace has the same permanent legal power as a court decision (inkracht van gewijsde).

The judge's decision on the deed of peace, as mentioned above contains a condemnatory decision that is a decision which punishes both parties to submit and obey all matters stated in the deed of peace. In addition to causing legal consequences in the form of binding parties to the contents of the deed, condemnatory decision also provides an executorial right for one of the parties to be able to force the contents of the deed forcibly with the help of the court when the other party is reluctant to voluntarily implement it.

In connection with the above statement, it can be concluded that if the notarial deed of peace is confirmed by a judge, then the deed will have permanent legal power as a court decision does (inkracht van gewijsde). Thus, in the event of breach of contract on the contents of the deed will give the right to the party who feels disadvantaged to be able to directly apply for the deed to the court without previously having to file a breach of contract lawsuit which will cause the claim to take a longer process.

The procedure for executing the notarial deed of peace that has been confirmed by a judge is the same as the procedure for the execution of ordinary court decisions that have permanent legal force. Execution in civil cases can be distinguished into three types as follows:

a. Execution of decisions that punish the losing party to pay a sum of money. This type of execution is regulated in Article $196 \mathrm{HIR}$ which states that the party who wins the decision can submit a written or oral application to the Head of the District Court who checks the case at the first level to enforce the decision forcefully. Based on the request, the Head of the District Court then summoned the losing party to be reprimanded for fulfilling the decision voluntarily within eight days after the warning was made. The If within eight days the losing party still does not voluntarily implement the contents of the decision or after he has been called appropriately, still does not come before the Head of the District Court, the Head of the District Court due to his position will give an order so that movable property of the losing party is to be confiscated. If the goods are not available or not enough to fulfill the contents of the decision, the immovable property of the losing party will be confiscated. 15

b. The execution of decisions that punish the losing party for committing an act. This type of execution is regulated in Article 225 HIR which states that the party to whom the action referred to in the decision must be made can submit a request in oral or written to the Head of the District Court who examines the case at the first level so that the deed must be assessed in an amount of money. The value of the act of the losing party is determined by the concerned Head of the District Court. ${ }^{16}$

\footnotetext{
${ }^{15}$ Mertokusumo, S. Op.Cit. p.256-257.

${ }^{16}$ Sutantio, R. Op.Cit, p. 135.
} 
c. Real execution. This type of execution is not regulated in the HIR, but is regulated in Article $1033 \mathrm{Rv}$ which states that if the judge's decision to empty the immovable property is not fulfilled by the convicted party to implement it, then the Head of the District Court checks the case at the first level by sending a written order to the bailiff and if necessary with the help of the tool of the state power so that the immovable property be emptied by the convicted party along with his family. ${ }^{17}$

\section{Conclusion}

The principle of ne bis in idem which is implicitly regulated in Article 1917 of the Civil Code is not contained in a breach of contract lawsuit filed against a party that does not implement a notarial deed of peace. Likewise, if the principle of ne bis in idem is reviewed by the provisions stated in Article 130 Paragraph (2) HIR not contained in a breach of contract lawsuit against the party that did implement the notarial deed of peace. This is due to the notarial deed of peace in the case was not confirmed by the court judge, so that the deed of peace was not equalized as a court ruling that had permanent legal force (inkracht van gewijsde), but was merely an ordinary agreement binding on the parties.

The notarial peace of deed is not confirmed by a court judge, then if it becomes the object of a case in court, it will have the same legal force as the legal power possessed by authentic deeds. The legal force of authentic deeds is firmly stipulated in Article 1870 of the Civil Code and Article 165 HIR, which is perfect evidence and binding on the parties, the heirs of the parties, as well as those who obtain the rights of the parties as long as there is no evidence submitted by the opponents that can stifle the legal power that he owns.

\section{References}

Books:

Ardhiwisastra, Y.B.( 2000). Penafsiran dan Konstruksi Hukum. Bandung: PT. Alumni.

Fuady, M. (2013). Teori-Teori Besar dalam Hukum (Grand Theory). Jakarta: Kencana.

Harahap, M. Y. (2008). Hukum Acara Perdata. Jakarta: Sinar Grafika.

Kusumaatmadja, M. (et.al.). (2000). Pengantar Ilmu Hukum Suatu Pengenalan Pertama Ruang Lingkup Berlakunya Ilmu Hukum. Bandung: Alumni.

Mertokusumo, S. (2009). Hukum Acara Perdata Indonesia, Yogyakarta: Liberty.

Situmorang, V.M. (et.al.). (1993). Grosse Akta dalam Pembuktian dan Eksekusi, Jakarta: PT. Rineka Cipta.

Sutantio, R.(et.al.). (2005). Hukum Acara Perdata dalam Teori dan Praktek, Bandung: Mandar Maju.

\section{Regulations:}

17 Hutagalung, S.M. (2010). Praktik Peradilan Perdata: Teknis Menangani Perkara di Pengadilan, Jakarta: Sinar Grafika, p. 108. 
Herzien Inlandsch Reglement (HIR).

Undang-Undang Republik Indonesia Nomor 02 Tahun 2014 tentang Perubahan atas Undang-Undang Nomor 30 Tahun 2004 tentang Jabatan Notaris (Lembaran Negara Republik Indonesia Tahun 2014 Nomor 3, Tambahan Lembaran Negara Republik Indonesia Nomor 5491). 